\title{
Behind the microphone
}

Election fever and new ways of campaigning were a colourful part of the 2001 Fiji elections. With the elections came innovative ways from the media industry in educating people and making them aware of issues.

\section{By TAMARISI DIGITAKI}

"Five more minutes!"

"Vijay, where's that story?"

"Malakai, we'll be crossing to you live. Hold on.....What?! Will someone check the feed from Malakai? Boys!!!"

"Where's my script?"

"Hell, I need a cigarette and coffee!"

IT'S ALMOST 7 o' clock on Sunday, 21 May, 2000. While the rest of the nation is just getting ready for the start of another day, Virisila Buadromo has been awake for almost 48 hours. Her eyes are burning and her throat scratchy from talking almost non-stop for hours. She is dead tired but adrenaline is pumping through her veins, pushing her on.

Since about 6am on Friday morning, the 28-year-old news director of Communications Fiji Ltd has not left her office building. She's hardly eaten anything, guzzling down gallons of coffee instead and sneaking outside for the occasional puff on a cigarette. Her petite body is screaming for a break but the excitement of the moment is just too much for her to give in to it.

What started off as another routine Friday morning for Buadromo quickly turned into a journalist's dream of Nirvana when George Speight and his cohorts stormed into the Fiji Parliament and took over government at gunpoint. On that fateful morning of 19 May 2000, Buadromo had walked into the newsroom with 


\section{INDEX}

a despatch plan for her team. There was going to be a protest march in downtown Suva and she had been warned by one of her male cousins that there was a real possibility of trouble erupting.

Fast forward to 2002 and Buadromo is reminiscing on the political mayhem of 2000 in her comfortable apartment,, which overlooks the exact city that was looted and burned on that fateful morning. "Because we all thought then that it was a racial issue, we decided that none of our Indo-Fijian or female reporters were going to cover the march," she remembers. Instead she marshalled off several Fijian male staff members to do the job, including Breakfast Show host, Tukini Cama and well-known sports commentator, Malakai Veisamasama.

Later that morning, the events manager for CFL received a call from her sister: "Something is happening in Parliament." she was told. Apparently, MP Ofa Duncan had called a friend from inside Parliament to say that Speight had just stormed into Parliament. Buadromo then pulled her news team from the protest march, directing them to Parliament instead. "Like a lot of other media people, I thought the action was going to be at the march," she says. "So we didn't send anyone to Parliament that morning." Through a mixture of persuasion, luck and persistence, Cama, Veisamasama and FM96 news editor, Vijay Narayan were eventually waved in.

Back in the studio, Buadromo was in a dilemma. "All the channels of information that we normally rely on were suddenly not working," she says. "The police were busy trying to control the riots in town, the army said it couldn't say or do anything until the police gave it the go ahead and the public service was basically defunct." To top it off, there was a severe shortage of reporters in the newsroom.

Buadromo's experience from her team's coverage of the 1999 crash of Air Fiji flight PC121 in Delailasakau, Naitasiri, kicked in. But as she puts it now, it was more a case of learning from mistakes than any act of brilliance. "Let's just say we made a lot of mistakes then," she observes. It was the first major news event she had to co-ordinate as news director and the absence of a CFL editorial policy for crisis coverage made her task even more daunting.

Early into their coverage, for instance, the issue of ethics became a tug-ofwar between her and management. One was over the release of names of the victims. While pressure was high from management to "break" the news, Buadromo felt there were legal and ethical issues to consider first. "I refused to air the victims' names because we had been told by the police that their next of kin had not been informed yet," she says. "For me, it was an issue of privacy. 160 PACIFIC JOURNALISM REVIEW 82002 


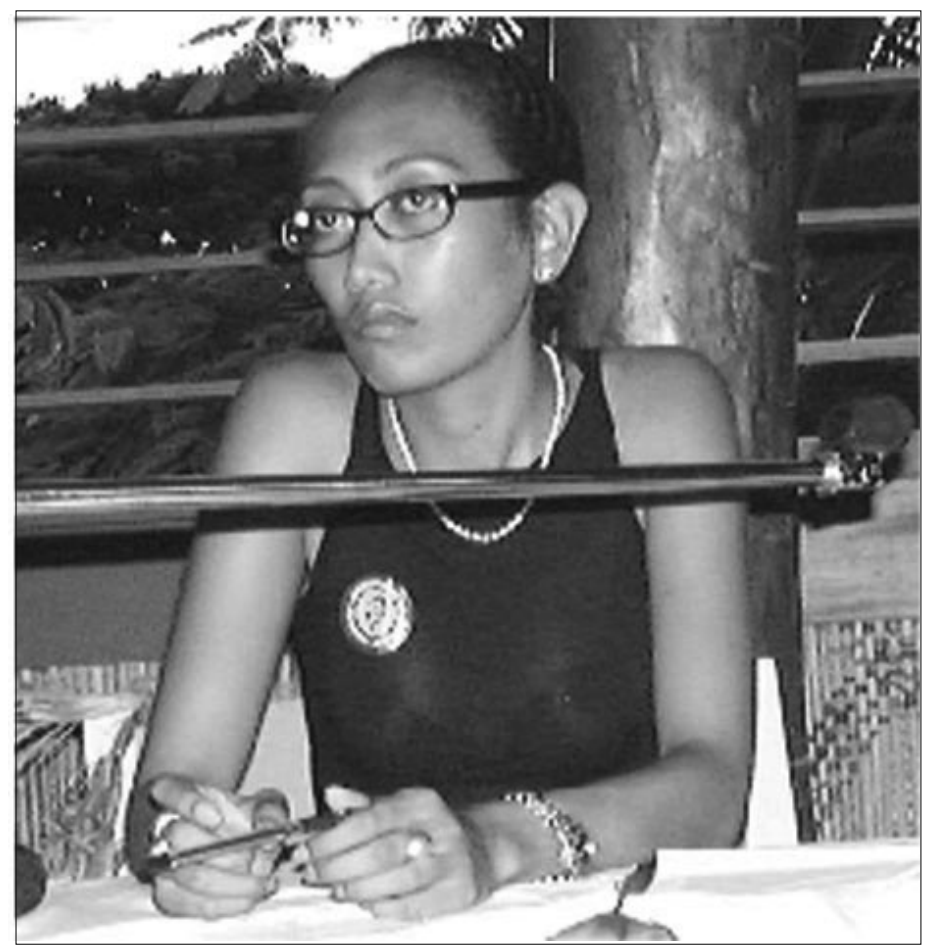

Viri Buadromo: "An issue of privacy" over air crash victims. Photo: WANSOLWARA ONLINE

It didn't seem right for them to hear of the death of their loved ones first over the radio."

The competitor released the unconfirmed list of victims and management came down hard on Buadromo. As they put it (and whether she liked it or not) radio was show business. As such, getting the highest rating was crucial especially for major news events. Other issues of contention were how far reporters should go when describing the crash site plus whether counselling was needed for reporters and other staff members who work directly on such cases. "For the first time, we had to consider all these things and we had nothing to guide us," she says.

That eventually led to the formulation of CFL's editorial board plus its first editorial policy on crisis coverage. Hence, when Speight and his cohorts stormed into Parliament, a better-prepared Buadromo plus news team was ready 


\section{INDEX}

to tackle the job. In fact, as soon as the take-over became known, the editorial board was re-activated.

One of the first problems they had to address was the shortage of reporters in the newsroom. But this was quickly resolved in an unexpected way. While Buadromo and her team were updating the nation on-air, the other CFL departments grinded to a halt and pitched in to help. Almost overnight, DJs, sales reps, accounts and administration personnel plus the management team became pseudo reporters, writers, drivers, cooks and counsellors. "It was a communal effort," remembers Buadromo with pride. "Everyone rose to the challenge."

But there were many more challenges to come. At one point during the team's coverage of the riots in Suva, it dawned on Buadromo and others on the board that their live reports were actually inciting some listeners to head for town and join the action. A decision was quickly made to stop all descriptive reports of the looting.

For the first 24 hours of the crisis, it was also decided that the team would merely report and not analyse any of the events. Furthermore, before any information was aired, it had to be verified by two reliable sources that had to be persons of authority. "In those early stages, this became very important because there were times when there was a lull in information and we were tempted to run with hearsay," explains Buadromo.

A crucial moment in the team's coverage came with whether on not Speight should be put on air. Buadromo had her reservations but it was finally decided by everyone on the editorial board that he had a right to express his views. It was a decision that would be heavily criticised later with critics saying it gave Speight too much publicity and glamorised his position. "He was part of the story so we had to give him fair coverage," defends Buadromo.

But important lessons were learnt from those early days. "I believe that the best coverage is one which covers all areas," says Buadromo. "There is never two sides to a story - there's more." This became particularly crucial as the hostage situation in Parliament dragged on into weeks. Information was flooding in and it fell on the editorial board to prioritise and streamline the news bulletins. Particular care had to be taken in how different reports were being relayed in the three different radio stations - FM96, Navtarang and Viti FM. The news was then broadcasted in English in all three stations with translations in the vernacular languages following each bulletin.

The low point for Buadromo was when she finally stepped out of the office two days after the looting and riots in Suva. "When I saw all that destruction, I 162 PACIFIC JOURNALISM REVIEW 82002 
just felt so sad and depressed," she remembers. "The reality of everything that I was putting on air finally hit me." Buadromo was going to be stuck again in the studio for most of the next 54 or so days. At home, her family and partner, Ashad, were fretting over her safety. Buadromo's parents are Seni, a former mayor of Suva and Liku, a homemaker. She also has four sisters and the only single one in the lot. But the out-spoken broadcaster was too busy working to spare a thought on this. "Even though we were getting bomb threats and threatening calls, I didn't really feel that my life was at risk in anyway," she recalls.

Her friends say this is so typical of Buadromo. Others were surprised at this plucky side of her. "Viri's always been outspoken," comments a friend. "She speaks her mind and is very assertive. But she's also a big lamulamu (one who gets frightened easily) so yeah, we were a bit surprised." Even Buadromo was surprised with her reactions to certain situations of the May 19 crisis. "I've always thought I would break down in a crisis but when it came to the crunch, I was surprisingly calm," she says with a smile.

Yes, there were moments of boredom and long waits, but Boadromo says she wouldn't have had it any other way because it was an exhilarating and eyeopening experience. Not least of which were the changes she saw in her news team. "I was able to pick out those who were committed and saw journalism, not as a stepping stone, but as a profession," she says. What particularly impressed her was how her team managed to stay motivated despite pay cuts, limitations in movement and resources being stretched to the limit. "I saw in them things that I hadn't seen before," she remarks. "It was as if the crisis was the catalyst they needed." On her part, she tried to encourage them along with regular pep talks, pushing the team work agenda and just being there with a sympathetic ear and a shoulder to lean on whenever they needed it.

She now says that it while it was relatively easy to keep her team going in the early days of their coverage ("because everything was so new and exciting!"), it increasingly became difficult as the days wore on. "I knew that the only way to motivate them was to lead by example," she says. Then she adds: "As an editor, you tend to think that everything you've been harping about is not getting through. But when a crisis happens and if you've been doing your job, then all that training suddenly kicks in."

For this one-time bartender, who fell into journalism quite by accident, her eight years of experience as a broadcaster and reporter has shaped much of her qualities as a worker and manager. She has moved on now, leaving CFL to join 


\section{INDEX}

the Fiji Women's Rights Movement as its co-ordinator. She's even contemplating on furthering her studies, "but I haven't decided yet".

But what she has left behind in CFL are lasting impressions. Says Narayan, her successor and the new CFL news director: "Viri gave us room to grow she basically trained herself out of the job. She was holding an executive position but she didn't make us feel less important because of that. She was a friend as well as the boss." And as those in authority know, it takes exceptional skills and patience to pull that off.

$\square$ Tamarisi Digitaki is a final-year journalism degree student at the University of the South Pacific and a former staff writer on The Review. This article was originally published in the April 2002 edition of Wansolwara, USP.

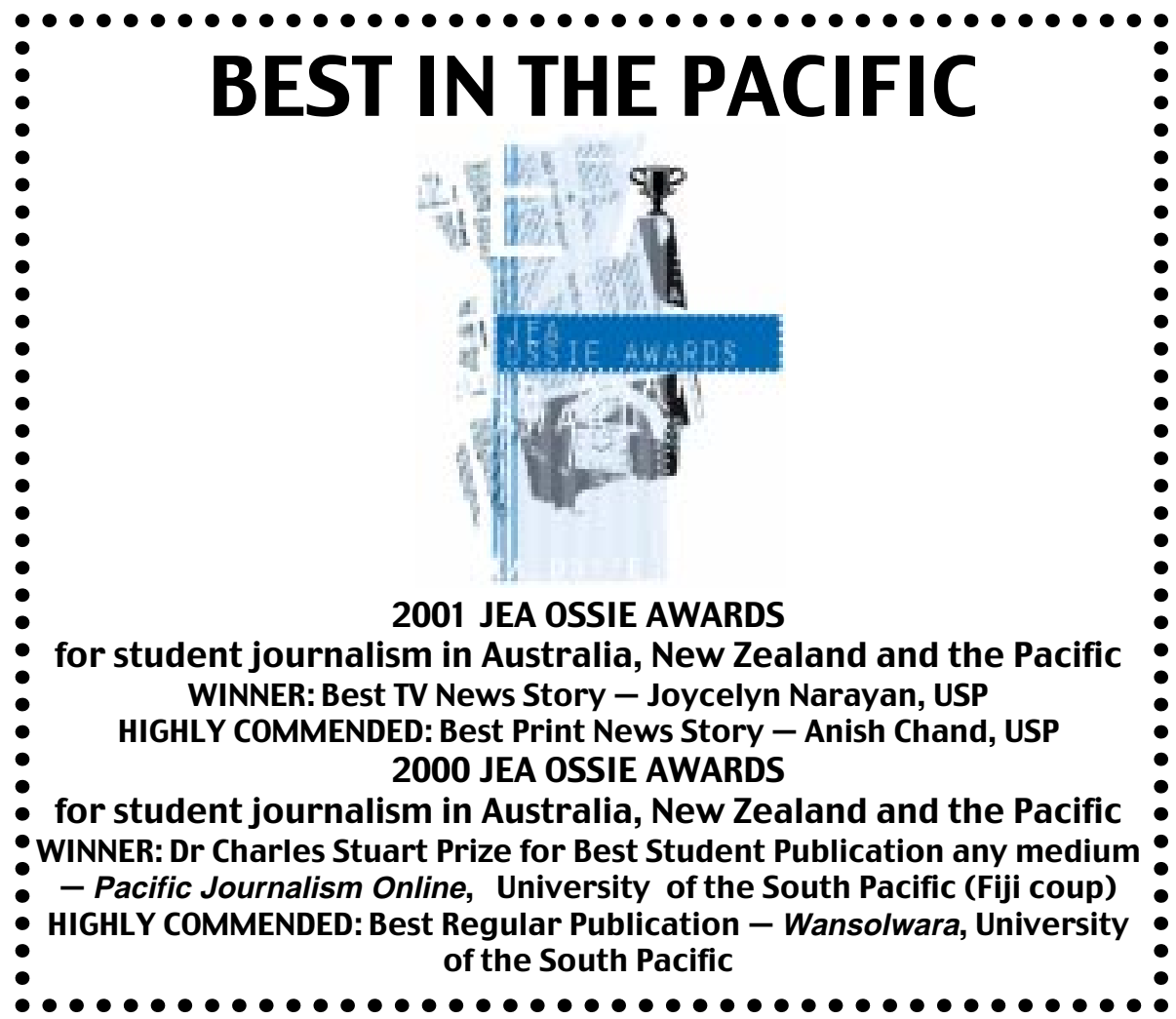

164 PACIFIC JOURNALISM REVIEW 82002 